\title{
Exhumations in post-war rabbinical responsas
}

\section{David Deutsch}

The purpose of this chapter is to offer an insight into post-war Jewish responsa (decisions and rulings made by scholars of Jewish religious law) addressing the issue of exhumation and reburial of human remains stemming from the Holocaust, following research into thirty responsas submitted by ordained and practising Orthodox rabbis. ${ }^{1}$ The first part of the chapter will provide a brief and general presentation of the jargon found in responsa literature, methodology and reasoning, as well as the shifts in social context regarding viewpoints and current views. In addition, the scant traditional, pre-Holocaust rulings concerning exhumations will be presented for juxtaposition with post-war responsas. The second part of the chapter pursues the analytic outlook, highlighting the 'forced' innovativeness of rabbinic verdicts. Due to the lack of a valid literary lineage addressing these issues, there was a great deal of legislative flexibility - hence, prompting a wide diversity in rulings.

Rabbinical responsa writing during and after the Holocaust received scant academic attention following the war. It was not until the mid-1970s that several scholars began to publish research dealing with this literature. As stated by Norman Lamn in the introduction to Rosenbaum's book on this topic, 'Rabbi Rosenbaum's work now hopefully begins to fill the lacuna in the history of Jewish heroism [responsa writing] during WW2', heroic because it displays the commitment to tradition under harsh persecution. ${ }^{2}$ Similarly, 
Zimmels' book, The Echo of Nazi Holocaust in Rabbinic Thought, contrasts the Holocaust with rabbinical literature in a wider context of rabbinical thought. Zimmels' book also provided translated responsas accompanied by brief analytic observations. ${ }^{3}$ Both aforementioned books were published by Ktav publication and both authors are well-known rabbinic figures. Despite their important contribution, the orientation of both writers was to glorify their body of research, rather than objectively evaluate the literature of this period. The same tendency to glorify and dramatise overrides a careful reading of the texts, as seen in Avineri's article published in the journal Sinai. ${ }^{4}$ Research published in the journal Dapim offered specific case studies, highlighting the problems and limitations of rabbinic authorities in the historical context during the Holocaust. Joseph Nedava presents an overview of the possible problems, ${ }^{5}$ whereas Meir Ayali focuses on one specific case: 'The Exchange of One's Life for Another's in the Responsa Literature. ${ }^{6}$ Both articles spotlight descriptive aspects of Holocaust rabbinical responsa and tend to avoid a normative assessment. In 1985, Dr Kirschner published his book, Rabbinic Responsa of the Holocaust Era, which finally contributed a comprehensive and historically contextual analytic outlook. However, the issue of exhumation hardly received any attention and academic research has not addressed the topic of responsas dealing with exhumations. ${ }^{7}$ Even in her recent work, Ester Farbstein prefers to highlight religious situations during, rather than after, the Holocaust. ${ }^{8}$ Some researchers tend to provide a general outlook; others focus on diverse Holocaust-related issues such as keeping kosher in the Ghetto, praying at the cost of risking one's life and religious conversion in order to save one's life, and so on. ${ }^{9}$ All of these detailed researches fell short of dealing with the issue of exhumation.

In light of the limited research, this chapter will engage itself with two challenges: (1) to provide a general and novel overview of the numerous rulings, and (2) to offer empirically based analytical observations to clarify the rulings. In the absence of religious literature dealing directly with mass reburial, rabbinic authorities faced the challenge of providing traditional legislation without 'traditional' sources. This void influenced decision making and had an impact on content, style and historical development, as evident in the diverse verdicts of the authorities. The answers delivered were primarily the outcome of two factors. First, there were no clear available traditional rulings and, second, rabbis were influenced by historical, social and ideological factors. 


\section{Traditional responsa literature and the issue of exhumation}

In Hebrew, reponsa writing is appropriately entitled 'Questions and Answers'. Reponsa originated as early as the third century AD in the form of letters of correspondence between Jewish scholars in Persia and Palestine, and the letters contained questions and dilemmas concerning Jewish law, rituals and traditions. Such correspondence later expanded to countries in every part of the Diaspora and over time the literature grew by leaps and bounds. The format, content and style of responsas changed throughout the years, influenced by the diverse localities and by the contexts of the rulings. The most significant shift, which is relevant to modern responsa, occurred after the publication of Rabbi Joseph Caro's Shulhan Aruch in the sixteenth century, which over time became the accepted codex of Jewish law. ${ }^{10}$ From this point on, responsa writing became less diverse, since the vast majority of rabbinical authorities were committed to the Shulhan Aruch's rulings. Isaac Klein provides a summary of the guidelines for some contemporary responsa:

1. Rulings should be based primarily on early rabbinic literature rather than in offering new interpretations.

2. Responsas should follow thematic framing of the Shulhan Aruch and be presented as a form of commentary on this legal codex.

3. Discussed topics should be narrowed down to legal and ritual rulings, excluding nearly all questions on faith and philosophy.

4. Responsas should be organised in a systematic manner with a complex methodology and reasoning.

5. Answers should be comprehensive with sources and previous rulings oftentimes re-examined. ${ }^{11}$

The issue of collective exhumation does appear in early Talmudic literature with regard to victims of the Betar massacres during the Bar Kokhba uprising against the Romans, ${ }^{12}$ since in this specific case of mass reburial the Talmud avoided providing a halakhic ruling. Later responsas disregarded the Betar story as a legal precedent.

Talmudic entries that are the basis for later rulings deal with individual, rather than collective, forms of reburial. The Shulhan Aruch introduced two verdicts concerning this issue that subsequently appear in most exhumation responsas. There are 
variations in interpreting the verdicts and disagreements on the degree of their relevance. Nevertheless, scholars base their argumentation on the same sources found in the Shulhan Aruch. The first ruling stipulates that an individual deceased in an open field may not be moved. In the case of an unattended body, the corpse 'buys' his place of burial, thus categorically redefining his place of death as a 'proper grave. ${ }^{13}$ The context of this ruling has financial implications: the owner of the property is forbidden to remove the corpse in order to use the soil. The second ruling specifies that a corpse should not be reburied, even if the new grave is more dignified. However, there are three exceptions in which reburial is permitted: (1) when the deceased is reburied closer to their forefathers; (2) when the bones are reburied in the land of Israel; (3) when the current burial place might be desecrated by gentiles. ${ }^{14}$

The first ruling deals with definitions of accepted burial and the second with conditions for reburial. Again the issue of exhumation and reburial, as it appears in early rabbinic writing, does not address mass reburial but, rather, specific cases of individual reburial. Even in the famous cases of multiple massacres that occurred in the Ukraine during the mid seventeenth century, the question of collective reburial was hardly addressed. Adam Teller's work shows that rabbinic authorities of the time focused their attention on other issues, such as permitting Agunot (women whose husbands had gone missing during the killings and so were uncertain of their marital status) to remarry. ${ }^{15}$

As noted, traditional halakhic literature did not deal directly with questions of mass reburial, so that in post-war responsas a great deal of interpretive freedom was displayed. Advocates of reburial based their argument on the second ruling and explained how conditions of the original burial justified exhumation. Rabbis that forbade reburial emphasised the first ruling and claimed that the place of murder is considered an adequate site for burial. The interpretive gap, along with the absence of a firm legal precedent, allowed the social and ideological context to influence the style and rulings of rabbinic literature. ${ }^{16}$

Further, advocates in favour of reburial presented unique features that were uncommon in traditional writings. For example, they tended to dramatise their narration, to include emotional characteristics in formal verdicts and to establish the Holocaust and exhumation rulings as a field of inquiry in their own right; thereby deviating from customary literary structures. ${ }^{17}$ 


\section{Responsa sources and statistics}

Various libraries and archives were exploited to collect sources for this chapter. Many responsas were found in the archives at the Yad Vashem Holocaust Museum in Jerusalem. Rare books were obtained from the National Library of Israel, the Institute of Hebrew Law on Mount Scopus and the Gush Etzion Library in Efrat. A relatively unknown archive, Ginzach Hashoa in Bnei Brak, provided me with rare materials that were available exclusively at that site. Naturally, the most accessible sources were the Holocaust responsa collection, which provided the bulk of materials for this research.

It is hard to obtain an exact number of exhumation responsas in the post-war responsa literature. However, the thirty responsas collected for this research provided a general outlook that is representative of the literature. The Bar Ilan Responsa Project, and more specifically its Holocaust collection, was used to access some of the less known responsas. I also conducted interviews with leading rabbinical authorities with experience in this field who directed me to references that were not found in common search engines. Since responsas tend to base their arguments on earlier rulings and include opposing arguments, I was also able to find references within the responsas themselves. ${ }^{18}$ Various written reviews that provide a comprehensive outlook on this issue are also primarily based on the aforementioned materials. ${ }^{19}$

After the war, the most prevalent question in responsa literature dealt with the exhumation of human remains from mass execution sites. Out of the thirty questions posed at the time, there are at least eleven entries directly related to mass exhumation. ${ }^{20}$ Besides corpses, the literature dealt with other types of human remains. For example, in nine cases the status of human ashes was discussed. This is highly relevant in the context of the Holocaust, since, after mass murder, crematoriums were often used to burn the corpses. In six entries, other types of human remains were discussed (bones, hair, fat, bloody soil, soap, ${ }^{21}$ teeth etc.), in terms of reburial and the potential to defile a Cohen (priestly caste). Four responsas discussed the issue of separation of bones before reburial (between individual Jews or gentiles and Jews). Another four responsas addressed the religious status of bones. ${ }^{22}$ Within this literature, the general tendency was towards burial of all forms of human remains. In regard to exhumations, opinions were split. Since the verdicts usually derive from basic rulings concerning reburial of a corpse, the exhumation policy of the responsas towards these types of human remains is just as ambiguous as with the reburial of corpses. 
A survey of the replies by rabbinical authorities reveals a diversity of opinions. These include a religious duty to rebury (4 verdicts); that it is forbidden to rebury (2 verdicts); an indecisive stance ( 2 verdicts); and a stance that cites dependence on the context of the specific case ( 3 verdicts). ${ }^{23}$ Nevertheless, most were in favour of the burial of ashes (not necessarily exhumations) and agreed that the status of ashes differs from that of an actual corpse. The actual question regarding the exhumation of ashes received only two opposing definitive answers - one for and one against.

Questions concerning remains were divided between a general format and those with a specific local context. For example, nine questions concerned the shooting pits used for victims in areas bordering the Baltic states and the death paths of the Einsatzgruppen units (for example, Tarnopol, Bochnia, Saramas, Konau and Kupishok), another five were related to concentration and death camp exhumations (Bergen-Belsen, Auschwitz), two were on exhumation from a Jewish cemetery and one was on exhumation, for survival purposes, in a Jewish Ghetto. ${ }^{24}$

The time frame on which this research is based concerns the postwar period up to the mid-1960s. Afterwards the topic of exhumation received limited attention, because of the rabbinical acknowledgement of the improbability of such an endeavour. Many of the writers (75 per cent) engaged in providing rulings on exhumations were Holocaust survivors themselves. Also, some prominent authorities, who dedicated books to Holocaust responsas, ${ }^{25}$ were inclined to deviate from traditional formalism, leaning towards a dramatic form of question presentation.

In a few cases, the author mentions the date when the answer was delivered or cites the individual who posed the question; nevertheless, generally there is little information concerning the precise date and origin of the questions in the formal version of the rulings. The length of the responsa questions varies between one sentence and one page, whereas the answers tend to be lengthy and entail a detailed argumentation process. Routinely, answers are between five and fifteen pages. As a general rule, responsas are written in Hebrew and combine some Talmudic Aramaic in the text.

\section{No precedent for collective exhumation}

Two opposing rabbinic attitudes regarding post-war exhumation were either to emphasise or to downplay mass reburial. Rabbis who 
emphasised mass burial not only permitted it but also highlighted its importance, whereas rabbis downplaying exhumations tended to rule against or even avoid dealing with this topic. Rabbis Efrati ${ }^{26}$ and $\mathrm{Oshri}^{27}$ advocated mass reburial; they dedicated their writings to this vision. Despite the lack of firm traditional legislation, Efrati's two published books focused on the rationale and duty of mass reburial. Oshri's comprehensive body of writings covered the obligation to rebury the victims. Furthermore, both authors shared the tendency to dramatise their text, a tendency that is rarely seen in traditional responsa literature. Efrati took advantage of the unprecedented nature of post-war mass graves and his Zionist ideology to link reburial with national identity. Four aspects, which deviate from traditional responsa writing, characterise Efrati's writings: designation of exhumation as a viable legislative issue, orientation of rulings towards Zionist ideology, dramatic presentation, and introduction of exhumation initiatives. These literary features exemplify the influence of the unprecedented reality encountered.

On the other hand, Sorotzkin ${ }^{28}$ and Greenwald, ${ }^{29}$ two UltraOrthodox (non-Zionist) rabbis, tried to avoid direct rulings on this issue; they generally ruled against intervention and explicitly criticised exhumation initiatives. Both were well aware that the traditional Shulhan Aruch rulings permitted reburial under certain conditions; nonetheless they argued that collective reburial dishonours the deceased. Their rulings are aligned within the greater context of original responsa writing, thereby avoiding the branding of their halakhic rulings as being specific to the Holocaust era. In addition to their disapproval of reburial, they share the tendency to evade, minimise or decontextualise exhumation as an issue in its own right. The basic polarities between rabbinic scholars in style and in their final rulings are the result of the absence of a firm precedent. The specific nature and orientation of the disagreement can be understood in light of religious, social and ideological dispositions.

\section{Efrati's early responsa literature}

The first responsa collection after the Holocaust that focused on the issue of exhumation was published in book form in Israel in 1948 by Rabbi Shimon Efrati, a Zionist Orthodox rabbi..$^{30}$ Rabbi Efrati was able to flee from Nazi rule and lived in Russia during the entire war. Nevertheless he suffered from the consequences of the Holocaust; he lost many family, friends and fellow community members from 
Bessarabia, Romania. In an attempt at rebuilding the community, Efrati returned to Eastern Europe immediately after the war only to encounter the post-war anti-Semitic pogroms. His first post-war impressions were that indeed Nazi rule had been defeated; however, violent European anti-Semitism still thrived. His attraction for Zionist ideology is related to his outlook on Diaspora Jewry; Efrati failed to see any hope in rebuilding Jewish life in Europe.

Efrati's first post-war compilation was called From the Valley of Tears (Be'emek Habacha) and dealt directly with the critical questions of exhumations and reburial of Jewish victims of the Holocaust. His writing deviates slightly from the generic and figurative form, as seen in the introductory preface, where he states: 'The book From the Valley of Tears, a halakhic inquiry of questions that derived from our people's great disaster and a horrific description of our martyrs' lives and deaths, may God avenge their deaths. ${ }^{31} \mathrm{He}$ continues by depicting a specific subject of inquiry, of 'bringing the ashes and bones of our holy ones to the land of Israel. ${ }^{32}$

A traditional classification of responsa writing usually follows one of the following models: (1) covers a broad issue such as Shabbat Laws, Dietary Laws etc., or (2) expands on a decision found in the Shulhan Aruch and presents it as commentary. Efrati's responsas, on the other hand, are somewhat atypical since the topic is very specific and deals solely with Holocaust and exhumation issues.

Efrati was not, however, the only rabbinical figure that provided extensive rulings on Holocaust issues. In 1959 Rabbi Ephraim Oshri began publishing his wide-ranging book of responsas dedicated solely to halakhic questions concerning the Holocaust. It was poignantly titled Mema'amakim, which is translated as 'From the Depths. ${ }^{33}$ His comprehensive five-volume collection covers religiously related Holocaust issues, including exhumations. ${ }^{34}$

Rabbi Oshri was an important rabbinic figure and represented the continuity of post-war Diaspora Orthodox Jewry. Initially, Oshri lived in the Ghetto Kaunas under Nazi rule, where he served as a formal rabbinic authority and provided religious rulings. After the war Oshri remained in Kaunas as the only serving rabbinical figure. During his early years as a rabbinic authority Oshri migrated several times to various locations within Eastern Europe. Thereafter, he migrated to the United States where he served in multiple rabbinic positions and published many responsas and books on halakhic issues.

While Oshri turns the Holocaust into an issue adequate for responsa classification, Efrati goes into further detail and 
highlights Holocaust victims' exhumation as 'book-worthy' material in its own right. He published two books, one in 1948 and a second in 1961.

A great part of Efrati's first book and more than half of his second publication (seven out of thirteen responsas) is dedicated to exhumation, burial and mass graves themes. Consistent with traditional literature, Efrati begins by presenting the context and content of the halakhic question at stake via the following narrative:

When I arrived at one of the towns in Eastern Galicia I met a dear Jewish scholar (religious scholar) from the Tarnopol community ... he led me to the death field wherein 10,000 Jews were buried ... in front of our eyes we encountered the magnitude of this horrific massacre; it is as if the sand is unwilling to cover this valley of death and shakes out human skeletons, skulls and other body parts ... a mother and child un-separated even in death ... I close my eyes to control the stream of tears ... and then I was asked the following question. 'Do we have a religious duty to exhume and rebury the bones in a Jewish cemetery? ${ }^{35}$

One of the trademarks of rabbinic responsas that focus on the Holocaust era is the dramatic form of introduction, which stands in noticeable contrast to the cold, formal and legal discussion that follows. Similarly, later responsas by Rabbi Oshri manifest the same tendency of dramatic rhetoric in the introductory presentation, followed by the purely analytical legal discussions. ${ }^{36}$

Efrati uses the traditional rhetoric of rabbinic reasoning, basing his arguments on the Shulhan Aruch, Babylonian Talmud, various postTalmudic writings and recent rabbinic works. The answer is finally delivered after a long and convoluted discussion, wherein the status of the temporary burial site is defined. In the main part of the legal discussion, there is no hint of any uniqueness to post-Holocaust exhumation nor any dramatic literary assertion. Despite minor variations, most responsas share the tendency of formal and traditional rhetoric and multiple approaches of argumentation. Rarely is an argument for a special ruling due to some extraordinary circumstance found. However, Efrati, when reaching his conclusion in favour of exhumation, reverts to his former warm-hearted style of writing - articulating pathos and drama, intermingled with religious rulings and Zionist ideology. His concluding statements, as quoted below, contextualise post-Holocaust Jewish exhumation within a pro-Zionist outlook:

Our holy pure martyrs who have been killed ... or buried alive in exile soil, their bones are scattered in open fields as a feast for vultures and 
wild animals ... it is permitted and furthermore a religious duty to bring them to proper Jewish burial may their souls rest there ... Of course there is no doubt that there is a religious duty to rebury them in the land of Israel, a land they longed for when brought to the gallows ... Here I address my tortured people, Dear brothers! At this hour and after 2000 years of exile we are privileged to have a Jewish state, we must not forget our martyrs that in their deaths enabled us to live ... I therefore call upon us to make a great effort in order to remove their bones from the lands saturated with their blood ... we shall take them over the great sea onto the shores of our holy land, there they will find peace. ${ }^{37}$

Efrati does not try to hide his Zionist orientation and creates an explicit partition between ' 2000 years of exile' and the reality wherein 'we are privileged to have a Jewish state'. The exile-redemption narration is reinforced by employing apocalyptic biblical metaphors describing the return to Zion: 'we shall take them over the great sea'. Two opposing images are presented here in the context of exiles: 'scattered bones in open fields' and, when reburied in Israel, 'they will find peace. ${ }^{38}$ Efrati delivers far more than a mere 'yes' or 'no' answer regarding reburial of Holocaust victims. He instead inaugurates a political context and an ideological dynamic into responsa writing.

Unlike the Ultra-Orthodox movement - a designated minority group at the time distanced from the mainstream Zionist movement in Israel - other Zionist Orthodox movements were driven to participate in the newly formed secular state and to promote the adoption of religious ideals and practices. Most of the Zionist rabbinical leadership rejected the idea of a state entity as a utilitarian formality and embraced religious and messianic ideas of national redemption. ${ }^{39}$ The issue of religion and state was a very practical one and resulted in formal constitutional acceptance, merging some religious ideals into the country's declaration of independence and incorporating religious regulations into state legislation. ${ }^{40}$

A correlation of Holocaust memory construction in the late 1940s and early 1950s with the birth of a Jewish state led to an implicit understanding between Orthodox and secular Zionists. Both saw Israel as an antithesis of the desperate reality of Diaspora Jewry. Both groups adopted the post-war mythical and apocalyptic narration - 'from holocaust to revival' - in the form of heroic imagery of Jewish resistance. ${ }^{41}$ The wide-ranging legislation that ensured the perpetuation of the memory of Holocaust victims in the 1950s was constantly linked to the Jewish state. Linear linkage between the Holocaust and Zionism was rarely contravened in Israeli public dialogue up until the early 1970s. It is within this 
context that several Zionist rabbis, including Efrati, published their legal responsas.

In his ruling, Efrati makes an unusual pronouncement: 'I hereby announce the establishment of a council that will devote its activities to bringing the bones of the deceased back to the land of Israel. ${ }^{42}$ This declaration goes beyond the conservative halakhic approach of restricting rulings to a specific case. It also entails Zionist ideological values that are absent in other responsas and upgrades the religious value of reburial in Israel. Typically, responsas limit themselves to reaching an accurate ruling and avoid social and political statements. Efrati, on the other hand, encourages participation in what is considered a noble enterprise and provides his personal home address: 'Gaza Street 16, Jerusalem. ${ }^{43}$ Efrati not only advocates a mass reburial endeavour; he calls for action and offers his participation. For Efrati, exhumation carries a significant ideological value.

A lack of precedent was the grounds for Efrati's interpretive freedom to articulate a Zionist conceptualisation at the heart of the responsa literature. ${ }^{44} \mathrm{He}$ generalises a religious duty towards individual victims and reframes traditional rulings to a national sphere. Efrati also establishes a discourse of ideologically oriented 'uniqueness' manifested by a dramatic style and the branding of post-war exhumations.

\section{Downplaying exhumation: Greenwald and Sorotzkin}

As with numerous other issues debated in the responsa literature, Orthodox authorities routinely fail to reach a unanimous verdict. The differences among scholars can be better understood in the greater context of the existing social dynamics. In addition to disagreements in their final verdicts, there are variations in literary style and in the framing of questions, and responsas conveyed by Greenwald and Sorotzkin demonstrate an opposing position to Efrati's pro-exhumation judgments. Both rabbis associated with an Ultra-Orthodox inclination display verdicts wherein exhumation initiatives and dilemmas are downplayed, undermined (Greenwald) or even explicitly forbidden (Sorotzkin). The degree of polarity hereby illustrated in their verdicts regarding exhumations can be linked to a lack of legitimate halakhic precedent.

Rabbi Yehoshua Greenwald served as the Rabbi of Khust before and during the years of Nazi rule in Ukraine. A greater part of the Khust community, including his wife and daughter, were either killed 
in shooting pits or deported to the death camps. After the war, Rabbi Greenwald was engrossed in the complex issue of permitting Agunot ${ }^{45}$ to remarry. He stayed in Europe for several years after the war and then migrated to the United States.

Greenwald dedicates a great deal of his book to Holocaust-related issues. He focuses on practical rulings concerning survivors, such as the various rulings permitting agunot Jewish women to remarry. In the preface, he recognises his sacred role in rebuilding post-war Jewish life and dedicates the book to his wife and daughter, who were murdered in Auschwitz. His dramatic historical introduction is delivered as a separate entity and is absent when he discusses his rulings. Nevertheless, the issue of exhumation is rarely discussed and only presented in an indirect manner.

Greenwald's early responsa, written in 1951, sets out two questions: '(1) can the priestly classes (Cohanim) touch and carry the ashes and; (2) is there a specific religious duty (Mitzva) to bury the ashes? ${ }^{26}$

The logic of combining these two issues is simple. According to Jewish law, a priest must not contaminate himself by touching or by carrying Jewish remains. However, not all remains have the capacity for causing contamination. The real question therefore comes down to whether ashes are classified as a corpse that can then contaminate.

Greenwald provides a long, intricate answer, unapproachable for a layman. He employs strict responsa methodology, wherein the final answer and summary are somewhat ambiguous and indecisive. However, he does clarify the point concerning whether it is better that a priest avoid any contact with the ashes when the upper spinal bone is not fully disintegrated. ${ }^{47}$ Regarding reburial, he offers a bold compromise: 'In my humble opinion, I think that it is sufficiently suitable if the ashes would be scattered around the gravesite; it is not imperative to fully rebury them. ${ }^{48}$

His topic deals with ashes, rather than actual corpses. Greenwald avoids direct confrontation with the issue of exhumation and thereby downplays the importance of reburial. Greenwald never contributes any halakhic decision dealing directly with corpses. Eventually, though, he modifies his answer on reburial of ashes and presents a new perspective: 'I therefore think that it is allowed to rebury the ashes along other gravesites. ${ }^{\prime 4}$ Greenwald was asked if there is a duty for this reburial, but he disregards the issue of religious duty and only addresses the question of 'if it is allowed. ${ }^{50}$ The reason for furnishing an ambiguous answer is the lack of previous rabbinic legislation - to provide a concrete ruling requires a basis in prior literature. 
The original context of the responsa questions was related to ashes found in Auschwitz. Local authorities limited rulings to the specific case in which the question was presented. Unlike Efrati's declaration calling for mass reburial, Greenwald ends his responsa with a short prayer for the rebuilding of the temple (a tradition wherein a short and formal request for Jewish redemption is expressed). There is no trace of national Zionist discourse or dramatic rhetoric. ${ }^{51}$ This is consistent with post-war Ultra-Orthodox rabbinic thinking that tried to minimise the gravity of Holocaust-related issues. Although Greenwald must deal with such questions as part of his formal rabbinic position, when it is not imperative, however, he attempts to steer clear of Holocaust-oriented issues.

Greenwald's ambivalent and indecisive verdicts display a middle way in regard to exhumation, wherein Holocaust memory is not over-emphasised nor is it linked to Zionism. Michal Shaul's research is highly relevant to Greenwald's historical context as part of American Orthodox Jewry. She differentiates Ultra-Orthodox memory constructs of the Holocaust from other forms of socially oriented Holocaust memory. She pinpoints the particular reasons behind the downplaying of Holocaust memory in Ultra-Orthodox communities in the early post-war years. This period posed a multilevelled challenge to Ultra-Orthodox Jewry: many devoted communities had vanished, thus arguments in favour of the Diaspora's format for Jewish identity were severely questioned. She illustrates how the later image of Holocaust destruction played a principal role in re-establishing Ultra-Orthodox identity. The Ultra-Orthodox memory of the Holocaust embedded the idea of the substantial Jewish destruction in order to advocate rebuilding of the Jewish way life. ${ }^{52}$ This form of memory is narrated in a different manner than the Zionist-Orthodox version; it focuses on rebuilding Jewish life rather than building a Jewish state.

\section{Exhumation as a disgrace}

A novel ruling, in terms of content and context, was delivered in the case of the Bergen-Belsen reburial project by Rabbi Sorotzkin. From 1954 onwards, Sorotzkin served as the head of the Council of Torah Sages, the rabbinic authority of the Ultra-Orthodox in Israel, as well as the Ultra-Orthodox autonomous educational system. He was widely accepted among Israeli Ultra-Orthodox communities and his rulings were seen as obligatory. After the French government 
decided to exhume 139 bodies, rabbinic authorities were forced to provide a legally binding halakhic opinion. Despite the different historical context, Sorotzkin shares Greenwald's tendency to downplay reburial and exhumations. ${ }^{53}$ But the Bergen-Belsen dispute warranted extensive attention by Rabbi Sorotzkin and other authorities since the exhumation process was already in motion; rabbinical authorities were 'cornered' into providing immediate answers. ${ }^{54}$

This case introduced the following problems: (1) Is it permitted? (2) What should be done with remains after exhumation? (3) When gentile and Jewish remains are intermingled, can Jews and non-Jews be buried together? Sorotzkin addressed these issues in detail.

He begins by disparaging the French exhumation and reburial project:

In regard to the question concerning the exhumation of our holy martyrs ... The rabbis of Agudath Yisroel [an Ultra-Orthodox party] in Europe have been asked whether we forbid it in later cases ... we are in one opinion that the bones of the deceased should not be dishonored by the meaningless chatter of these so called 'experts'. In general the deceased should not be disgraced due to the will of the French government. ${ }^{55}$

Sorotzkin offers three reasons for condemning reburial:

(1) It is forbidden to exhume and rebury the bones of one individual wherein the bones of another will be dishonoured. By exhuming the massive burial site in order to extract specific remains, the 'other' unattended bodies are considered dishonoured.

(2) In the process of reburial; bones from different victims will be mixed together which is absolutely forbidden. If these bones are already mixed however, the responsible party for these actions is the original killers. The action of deliberately mixing up the bones of the deceased afterwards is absolutely forbidden. This decision is especially relevant in the case where there is a possibility of Jewish and gentile remains being buried together. This would be a great disgrace for them ...

(3) ... an unattended corpse (Met Mitzva) buys (thus enacting its own category of religious burial) its place of burial. There is peace for the soul when the body stays at its original place of burial ... perhaps the burial place of the deceased at the killing site awakens God's judgment for vengeance. ${ }^{56}$

As Menachem Rosensaft pointed out, American UltraOrthodox authorities were in tune with Sorotzkin's verdict 
forbidding exhumations. Rabbi Moses Feinstein, president of the World Council of Torah Sages, and other leading American figures (Rabbi Abraham J. Heschel, Rabbi Wolfe Kelman and Rabbi Joseph H. Lookstein) were explicitly against the French exhumation initiative. In contrast, Rosensaft highlights the different tendencies of the Israeli rabbis. Chief Rabbis of Israel at the time displayed a more permissive approach towards reburial and the specific case of the Bergen-Belsen exhumation initiative. ${ }^{57}$ Bergen-Belsen was possibly different since it originated as a secular initiative of the state. Nevertheless, arguments provided in these specific responsas, as well as issues previous responsas tended to avoid, can help provide a better understanding of the Ultra-Orthodox outlook regarding post-war exhumations. ${ }^{58}$

Sorotzkin's ruling stands in direct contrast to those of Efrati, who suggests minimising the disgrace of those killed by reburying them in the Holy Land, whereas Sorotzkin perceives exhumation and reburial as an act of disgrace to the remains. Sorotzkin and Efrati are well aware of the Talmudic ruling concerning an unattended corpse (Met Mitzva): given that the deceased is an unattended corpse, the Talmud expropriates the place of burial from any previous owner and awards it to the deceased - an officially categorised place of burial therefore 'belongs' to the corpse. Thus, the corpse 'redefines' the place of burial as a proper grave. Although the legitimacy of the Talmudic source is unanimous, the responsa writers argue about the relevance of this ruling to post-war mass burial. Sorotzkin bases his ruling on this Talmudic precedent, whereas Efrati stresses the traditional ruling cannot be applied in this case: 'when they said that the unattended deceased [Met Mitzva] buys his place of burial they have meant that he owns the land nevertheless reburial is permitted. ${ }^{59}$ In other words, Efrati limits the Met Mitzva ruling to a financial aspect of ownership rather than to burial laws. For Sorotzkin, the inescapable reality of the victims' disgrace is rhetorically utilised to stimulate God's retribution. He affirmed how the problematic reality of mass burial can play a functional role in religious argumentation and presented a logical discourse for advocating against an intervening action, since 'the killing site awakens God's judgment for vengeance.'

How can the same action be classified by such a diametrically opposite normative status? The elastic quality of how the exhumations were evaluated is the result of the different interpretive possibilities. The lack of a firm, assertive and tangible tradition on collective reburial opened the door for diverse explanations. Social 
and ideological orientations of authors also played a role in influencing the rulings.

Unlike Efrati, Sorotzkin and Greenwald were non-Zionist and Ultra-Orthodox. During the early post-war years, the UltraOrthodox movement tried to avoid or limit any direct confrontation with Holocaust issues. It was only later that movements such as Agudath Yisroel and others created perspectives on the role and significance of the Holocaust in religious and ideological rhetoric. ${ }^{60}$ Efrati, who was a Zionist and worked as an official state-enrolled rabbi, published his responsas with the Rav Kook publishing house, a Zionist-leaning organisation. His book is in tune with his ideological connection between the Holocaust and the land of Israel and this link appears on the very first page.

Another famous Jewish scholar, Rabbi Waldenberg, was oriented against reburial. His responsa, Tzitz Eliezer, began around 1945. The first volume, which included questions on exhumation, was published in 1959, two years before Efrati's second book came to light. Waldenberg does not deal directly with exhumation of a corpse, but focuses on secondary remains, ashes and soap. ${ }^{61} \mathrm{He}$ follows Greenwald's line in avoiding the direct question of reburial. Nevertheless, implicit conclusions concerning reburial of actual corpses can be drawn.

He begins with two questions: ' 1 . Is it permitted to rebury a coffin that holds soap and fat made from holy martyrs; 2 . Is there a religious obligation to bury such soap and fat. ${ }^{62}$ Although Waldenberg's argument is short, he concludes that ' $[\mathrm{t}]$ here is an obligation to bury the soap ... since there is no doubt that partial bones can be in it ... Therefore I warn not to open the burial sites nor should they be exhumed. ${ }^{63} \mathrm{He}$ stresses that ashes should also be buried but not exhumed and reburied. Like Sorotzkin, Waldenberg perceives exhumation and reburial of human bones or remains as a disgrace to the deceased.

Despite Sorotzkin's, Greenwald's and Waldenberg's explicit or implicit opposition, many Zionist authorities, immediately following the war, favoured the idea of reburial. Rabbi Frank, for example, who later became the Chief Rabbi of Israel, published a responsa that advocated reburial. His answer is contradictory. Alongside his categorical statement that exhumation is improper, he elaborates on the fundamental logic for reburial:

there is an obligation to bury for two reasons: honoring the living and honoring the deceased: First the dead should be honored and second 
forgiven. A spiritual need of forgiveness after death is well recognized (one provided by the ritual of burial) even for a body that was burnt to ashes. There is a similar idea found in Gittin [Tractate in the Talmud]. There is much more to be written and I can prove this point further ... That these ashes must be properly buried, yet it is hard for me at this point to write about this topic in detail. ${ }^{64}$

It is widely accepted that proper burial honours the deceased; the real question at stake is whether reburial would be more honourable. This question was entangled within a wider setting, wherein political and ideological powers influenced post-war rulings, argumentation, logic and even literary style.

\section{Conclusion: the years after the precedent}

Although rulings concerning exhumation displayed diversity and contradictions, all authors shared the same challenge: how to deliver verdicts without a viable precedent? I have tried to demonstrate how this deficiency influenced the verdicts of rabbinic authorities. Efrati and other Zionist rabbis took the interpretive liberty to emphasise an ideological orientation; whereas non-Zionist Orthodox rabbis endeavoured to minimise the distinctiveness of collective exhumation and to integrate reburial into a wider and more general legal context.

In the absence of precedent, the first rulings focused on basic and fundamental issues of post-war exhumation. Nevertheless, during the late 1950s and early 1960s the scope of exhumation responsa literature was expanded and in some cases revised. Only after establishing a precedent could rabbinic authorities attend to additional topics as well as modify their rulings. Two leading literary shifts can be noticed here: (1) expansion of the exhumation issues (detailed rulings), and (2) a shift towards more pragmatic rulings.

(1) The tendency to pay attention to wide-ranging questions and to other forms of human remains can be seen in Oshri's responsas. His writings, which began with corpses in early post-war responsa literature, were later expanded to secondary artefacts that potentially held human remains; questions were introduced on various forms of remains, such as ashes and bones. The responsa writing of the late 1950s and early 1960s became even more comprehensive and provided rulings concerning hair, bones mixed together with other materials, teeth, soap, human fat and even tombstones, as described in his writing: 'Is it permitted to walk in streets that are 
made out of tomb stones that were taken from Jewish cemeteries ... I was asked: what is the status of these stones? Can one walk in these streets, step on these stones? ${ }^{65}$

Oshri introduces additional and detailed secondary questions: Can a grave be re-dug in order to extract a jewel and return it to its owner in the Ghetto? ${ }^{66}$ Should a deceased person who lived with gentiles during the war be given a Jewish burial ${ }^{27}$ During the Holocaust can a person request that his body be burned and his ashes buried in order to prevent himself from being buried among the gentiles? ${ }^{68}$ What is the ruling on reburial of an assimilated Holocaust victim? Oshri's contribution was highly significant since he was the first to provide a wide-ranging outlook on the subject matter by the publication of a comprehensive three-volume work dedicated solely to responsas concerned with issues related to the Holocaust.

(2) An example of a literary change towards pragmatic rulings - from one general and impractical towards rulings that take temporal conditions and limitations into account before providing their halakhic ruling - can be seen in Efrati's later verdicts. In 1961 Efrati altered his ruling concerning exhumation, offering a more pragmatic and moderate solution by downplaying the obligation to rebury. Further, in his 1961 ruling, Efrati does not advocate reburial in Israel but tolerates local cemeteries in Europe. A decade after his enthusiastic call for bringing the bones to Israel, Efrati became aware of the limitations of his decisive ruling - it was not feasible for all victims to be reburied nor could they all be brought to Israel for reburial. Therefore, the 1961 entry does not call for a major reburial project and moderates the concept that it is a religious duty incumbent on every member of the faith. He tends to present the case as a right to rebury, rather than an obligation.

A new issue covered in the latter responsa deals with the sanctity of the original death pit. He argues as follows: 'those holy places wherein martyrs were buried should stay forever deserted ... after their reburial ... to build a fence around the site and leave it as is for an eternal memorial. ${ }^{69}$ Although Efrati repeatedly argues in favour of reburial in the Holy Land, he sanctifies the locations where mass burial took place all over Europe, thus opening the door to an alternative. If these pits are as holy as a Jewish cemetery, the necessity to exhume the remains is diminished.

Efrati's earlier ruling was a reaction to what he defined as an unprecedented reality, and his 1948 book was consistent with this outlook. After failing to implement a large-scale exhumation initiative, Efrati concentrated on more practical rulings, although the 
1948 verdict advocating mass reburial fell short of yielding results. Rabbinical authorities are well aware that any rulings not within a reasonable capacity to be carried out by the Jewish people should be avoided. Awareness of this concept forces Efrati to reorient his own previous judgments.

Due to the lack of traditional responsa literature regarding collective exhumations, rabbinic authorities were cautious about articulating any basic or far-reaching opinions. The first wave of responsa verdicts tended to deal with immediate and general questions of exhumations. Rabbis who were in favour were more occupied with grounding their fundamental arguments to initiate reburial rather than offering a comprehensive outlook on the topic. However, in the late 1950s and early 1960s two changes became evident. More types of cases of exhumation are taken into account and rulings are more detailed. Furthermore, rabbinical authorities pay more attention to the actual conduct (rather than their general pro or con verdicts) of these reburial initiatives.

\section{Notes}

1 Although there is conservative and reform responsa literature, I have not yet found any reference to writing on this topic from any of their sources, thus this research is limited to Orthodox responsa. The analysed source material and the responsa historical background of exhumations are therefore oriented towards the Orthodox outlook.

2 I. Rosenbaum, The Holocaust and the Halakha (New York: Ktav Publishing House, 1975). See editor's foreword.

3 H. J. Zimmels, The Echo of Nazi Holocaust in Rabbinic Thought (New York: Ktav Publishing House, 1977).

4 I. Avineri, 'The Halakhic literature during the Holocaust', Sinai, 92:3-4 (1982), 172-88.

5 J. Nedava, 'Problems of Halakha in the ghettos', Dapim, 1 (1978), 44-57.

6 M. Ayali, 'The exchange of one's life for another's in the responsa literature, Dapim, 3 (1984), 43-51.

7 R. Kirschner, Rabbinic Responsa of the Holocaust Era (New York:Schocken Books, 1985).

8 E. Farbstein, Bester Raiam: Halakha, Jewish Thought and Rabbinind Leadership during the Holocaust (Jerusalem: Rav Kook Institute, 2001).

9 For some topics, see the work of Farbstein in relation to Rabbi Aharonson's writing during the Holocaust; E. Farbstein, 'Religious ruling and halakha in the writing of rabbi Aharonson', Sinai, 108 (1996).

10 At first this codex encountered opposition, especially from East European rabbinical authorities. However, after its publication with the commentary of East European Rabbi Moses Isserles, Caro's book became widely accepted. 
11 I. Klein, Responsa and Halakhic Studies (New York: Ktav Publishing House, 1975).

12 Babylonian Talmud, Massechet Brachot, 48, 2.

13 Rabbi Joseph Caro, Shulhan Aruch, Yoreh De'ah, 364, 3.

14 Ibid., 363, 1-3.

15 See A. Teller, 'Literary responses to the events of 1648-1649 and the creation of a Polish-Jewish consciousness', in B. Nathans and G. Safran (eds), Culture Front: Representing Jews in Eastern Europe (Philadelphia: University of Pennsylvania Press, 2008), pp. 17-45.

16 For example, Zionist vs non-Zionist or Israeli Jewry vs American Jewry.

17 However, responsa writing methods stayed well within the boundaries of traditional writing set centuries ago. This holds true not only for the post-war issue of exhumations but also for rulings relating to life and death, and questions arising during the Holocaust itself. Interestingly, the agreement on the methodological form of argumentation did not mean that the rulings were identical.

18 The research and the collection of this material was financed by the generous funding of the research programme 'Corpses of Mass Violence and Genocide', funded by the European Research Council.

19 Y. Chazani, 'Bringing bones from the diaspora', in Zomet Institute (ed.), Tchumin, vol. 13 (Gush Etzion: The Zomet Institute).

20 In fact, sixteen entries introduce the issue of reburial in general. However, the following cases have been limited to where actual corpses or bones were explicitly discussed.

21 Although scholars have disproved the myth that soap was made from Jewish human remains, the image of soap made out of victims was widely and commonly accepted. This also holds true for rabbinic figures who believed that soap made out of martyrs should be buried. Therefore some responsas give verdicts regarding post-war myths and not only post-war realities.

22 Some responsas address more than one issue in the same answer, meaning the numbers overlap.

23 The statistics hold for responsa entries even when delivered by the same author.

24 The question was published after the war but the issue at stake took place during the Holocaust.

25 For example, Rabbi Shimon Efrati and Rabbi Ephraim Oshri, later discussed in detail.

26 S. Efrati, Be'emek Habacha (Jerusalem: Rabbi Kook Institute, 1948);

S. Efrati, Megei Hahariga (Jerusalem: Yehuda Publications, 1961).

27 E. Oshri, Mema’amakim (New York: Modern Linotype, 1959).

28 Z. Sorotzkin, Moznaim Lamishpat (Jerusalem: Mesora Publications, 1956).

29 Y. Greenwald, Chesed Leyehoshua (New York: Shulsinger Brothers, 1951).

30 Efrati, Be'emek Habacha.

31 Ibid., introduction.

32 Ibid.

33 The name of his book corresponds with a famous verse from Psalm 130. 
34 Oshri, Mema'amakim.

35 Efrati, Be'emek Habacha, part 5.

36 Oshri, Mema'amakim, pp. 2, 20.

37 Efrati, Be'emek Habacha, part 5.

38 Efrati's wording possibly refers to biblical expressions that can be seen in Jeremiah, 8, 2; furthermore, the image of the rebirth of bones was a very famous religious metaphor used by Zionist rabbis and appears in Ezekiel 37.

39 For a comprehensive and analytic review, see A. Ravitsky, Messianism, Zionism and Jewish Religious Radicalism (Chicago: University of Chicago Press, 1998), ch. 2.

40 Dobrin illustrates some social outcomes of the religious legislation hybrid. See N. Dobrin, 'Israelis married abroad with special reference to the immigrants from the former Soviet Union', Megamot, 44:3 (2006), 477-506.

41 See B. Cohen, 'Holocaust heroics: ghetto fighters and partisans in Israeli society and historiography', Journal of Politics and Military Sociology, 31:2 (2003), 197-213.

42 Efrati, Be'emek Habacha, part 5.

43 Ibid.

44 The reason I focus upon the lack of literary precedent is due to the fact that mass burial and the question of reburial did indeed come up (the deceased in Beitar city). However, mass burial was never addressed in responsa literature before the Holocaust.

45 These are women who have not received a religious divorce since their husbands were missing and presumably dead.

46 Greenwald, Chesed Leyehoshua, pp. 1, 4.

47 Greenwald bases his argument upon Talmudic (Babylonian Talmud, Masechet Nida, 70, 1) discussions and earlier (pre-Holocaust) responsas.

48 Greenwald, Chesed Leyehoshua.

49 Ibid.

50 Ibid.

51 Nonetheless advocacy for rebuilding post-war Jewish life on the basis of the Holocaust can be found in his introduction.

52 M. Shaul, 'The regeneration of Ultra-Orthodox (Haredi) society after the Holocaust: starting with the old', Iyunim Bitkumat Israel, 20 (2010), 360-95. She further explains their perception that it was meant to reestablish Torah centres and contribute to the growth of Ultra-Orthodox communities.

53 Rabbi Sorotzkin served as the Rabbi of Dzyatlava (Belarus). He was able to flee to Minsk just before the First World War. In 1939 Rabbi Sorotzkin again fled conflict, this time landing in Palestine. Sorotzkin assumed a leading position in the Orthodox rabbinic elite in Israel and in 1954 he was appointed as chairman of the Ultra-Orthodox council. A great deal of his efforts were focused on differentiating the Ultra-Orthodox minority from the rest of Israeli society, namely by establishing a separate educational system. Although Sorotzkin indeed served as a rabbi in Israel, he was a non-Zionist; he believed that the state of Israel is another form 
of living in exile. He therefore refused to see the idea of a Jewish state related in any way to the religious prophecy and ideal of redemption.

54 Z. Sorotzkin, Moznaim Lamishpat (Jerusalem: Mesora Publications, 1956), pp. 2, 15.

55 Ibid., pp. 2, 15.

56 Ibid.

57 M. Z. Rosensaft, 'The mass-graves of Bergen-Belsen: focus for confrontation', Jewish Social Studies, 41:2 (1979), 155-86.

58 For a detailed and contemporary account of the Bergen-Belsen exhumation dispute, see J.-M. Dreyfus, Ami si tu tombes: Les déportés résistants des camps au souvenir 1945-2005 (Paris: Perrin, 2005).

59 Efrati, Be'emek Habacha, part 5.

60 Shaul, 'Regeneration of Ultra-Orthodox (Haredi) society', 383-4.

61 As already mentioned, the soap myth can be seen in several responsas addressing the issue.

62 See E. Y. Waldenberg, Tzitz Eliezer (Jerusalem: Solomon Publications, 1959), pp. 8, 35. Responsas addressing the legend of soap created from human bones are common. In fact, this same question appears in the responsa Piskei Uziel in B. Z. M. C. Uziel, Piskei Uziel (Jerusalem: Rabbi Kook Institute, 1977), part 37.

63 Ibid.

64 Frank, Yoreh De’ah, part 275.

65 Oshri, Mema'amakim, pp. 2, 20.

66 Ibid., pp. 2, 12; the question was asked under Nazi rule in the Ghetto and was published later in Oshri's collection.

67 Ibid., pp. 1, 25.

68 Ibid., p. 3.

69 Ibid.

\section{Bibliography}

Aharonberg, Y. M. M., Dvar Yehoshua (Israel: Self-published, 1970)

Avineri, I., 'The Halakhic literature during the Holocaust', Sinai, 92:3-4 (1982), 172-88

Ayali, M., 'The exchange of one's life for another's in the responsa literature, Dapim, 3 (1984), 43-51

Breish, M. Y., Chelkat Yaakov (Tel Aviv, 1951)

Caro, J., Shulhan Aruch, Yoreh De'ah (Vilna: Romm Publication House, 1883)

Chazani, Y., 'Bringing bones from the diaspora', in Zomet Institute (ed.), Tchumin, vol. 13 (Gush Etzion: The Zomet Institute)

Cohen, B., 'Holocaust heroics: ghetto fighters and partisans in Israeli society and historiography', Journal of Politics and Military Sociology, 31:2 (2003), 197-213

Dobrin, N., 'Israelis married abroad with special reference to the immigrants from the former Soviet Union', Megamot, 44:3 (2006), 477-506

Dreyfus, J.-M., Ami si tu tombes: Les déportés résistants des camps au souvenir 1945-2005 (Paris: Perrin, 2005) 
Efrati, S., Be’emek Habacha (Jerusalem: Rabbi Kook Institute, 1948)

Efrati, S., Megei Hahariga (Jerusalem: Yehuda Publications, 1961)

Farbstein, E., 'Religious ruling and halakha in the writing of Rabbi Aharonson', Sinai, 108 (1996)

Farbstein, E., Bester Ra'am: Halakha, Jewish Thought and Rabbinind Leadership during the Holocaust (Jerusalem: Rav Kook Institute, 2001)

Frank, T. P., Har Tzvi (Jerusalem: El Hamkorot Publications, 1957)

Geshtetener, N., Lehorot Lenatan (Bnei Brak: Lipa Friedman Publications, 1973)

Greenberg, G., 'War time American orthodoxy and the Holocaust: Mizrachi and Agudat Israel religious responses', Michael: On the History of the Jews in the Diaspora, 15 (2000), 59-94

Greenwald, Y., Chesed Leyehoshua (New York: Shulsinger Brothers, 1951)

Henig, N., Tiferet Naftali (Brooklyn: Nechmad Publications, 1986)

Kirschner, R., Rabbinic Responsa of the Holocaust Era (New York: Schocken Books, 1985)

Klein, I., Responsa and Halakhic Studies (New York: Ktav Publishing House, 1975)

Nedava, J., 'Problems of Halakha in the ghettos', Dapim, 1 (1978), 44-57

Oshri, E., Mema'amakim (New York: Modern Linotype, 1959)

Ravitsky, A., Messianism, Zionism and Jewish Religious Radicalism (Chicago: University of Chicago Press, 1998)

Rosenbaum, I., The Holocaust and the Halakha (New York: Ktav Publishing House, 1975)

Rosensaft, M. Z., 'The mass-graves of Bergen-Belsen: focus for confrontation', Jewish Social Studies, 41:2 (1979), 155-86

Shaul, M., 'The regeneration of Ultra-Orthodox (Haredi) society after the Holocaust: starting with the old', Iyunim Bitkumat Israel, 20 (2010), 360-95

Sorotzkin, Z., Moznaim Lamishpat (Jerusalem: Mesora Publications, 1956)

Stern, B., Betzel Hachochma (Jerusalem, self-published, 1959)

Teller, A., 'Literary responses to the events of 1648-1649 and the creation of a Polish-Jewish consciousness', in B. Nathans and G. Safran (eds), Culture Front: Representing Jews in Eastern Europe (Philadelphia: University of Pennsylvania Press, 2008), pp. 17-45

Uziel, B. Z. M. C., Piskei Uziel (Jerusalem: Rabbi Kook Institute, 1977)

Waldenberg, E. Y., Tzitz Eliezer (Jerusalem: Solomon Publications, 1959)

Yablonka, H., 'The law of punishment the Nazis and their collaborators: legislation implementation and attitudes', Cathedra, 82 (1996), 135-52

Zimmels, H. J., The Echo of Nazi Holocaust in Rabbinic Thought (New York: Ktav Publishing House, 1977) 